Torben Dressler

ORCID: 0000-0002-8376-6532

Uniwersytet Wrocławski

torben.dressler@gmx.de

\title{
Sovereign Money
}

Date of submission: $5^{\text {th }}$ of March 2018; date of acceptance: $20^{\text {th }}$ of April 2018

JEL Classification: G00

Keywords: Sovereign Money, 100\% Money, Vollgeld

Abstract

Sovereign Money

The aim of this paper is to point out the commonalities and differences between the two currency reform approaches " $100 \%$ Money" and "Sovereign Money". The definition of " $100 \%$ Money" was taken from Irving Fisher, the definition of "Sovereign Money" from Joseph Huber. The biggest commonality of these two approaches is the aim to end or to ease financial crises, the biggest difference is the way this money gets booked. This paper is interesting for students and teachers of finance, especially if they are experts in money theory.

\section{Introduction}

The following paper examines and compares two reform approaches for the currency system. By name these are "Sovereign Money" and "100\% Money". Both approaches share the claim to be the better currency system that leads to more economic stability. Thise topic is current because Switzerland has faced an interesting discussion during the past few months. A federal popular initiative with the title Für krisensicheres Geld: Geldschöpfung allein durch die Nationalbank! (for crisis-proof money: money creation alone by the national bank), also called "Vollgeld-Initiative" has set off a discussion about the reformation of the Swiss currency system.

The "Vollgeld-Initiative" postulates a currency system which is known as Sovereign Money in English language. The core claim of this initiative is that only the Swiss national bank should be allowed to create Swiss francs - comprising 
banknotes, coins and electronic money on bank accounts. The aim is converting money in bank accounts into "real" Swiss francs. Although this initiative was rejected by the national council, the council of states, and the federal councilor, this does not necessarily mean an end of the consideration implementing this system (Schöchli 2017). According to the initiators this initiative was rejected due to the fact that either the politicians did not understand the proposed system or acted in the interests of profiteers of the current system (Brächer 2018).

But what is Sovereign Money exactly? Sovereign Money means a fullyfledged legal tender where the complete money gets declared as statutory means of payment (Huber 2014). This concerns cash as well as deposit money. This prevents commercial banks from creating money on their own. It also means the end of blending loans and money creation by private institutions. The commercial banks would still be responsible for lending money. The crucial difference is that loans have to be refinanced entirely. Entirely financing means that a commercial bank is only allowed to lend money that they either own or their customers made available for them (Kumhof \& Benes 2012, p. 7).

In a Sovereign Money system the central bank has complete control over the money supply. In contrast to the private banking money system, the central bank creates not only 10 but 100 percent of the money supply. The central bank decides directly and independently what amount is circulated. This concept earmarks a constitutional status for the money supply. The central bank gets upgraded to a "monetative" and supplements the legislative, executive, and judiciary (Degens 2013, p. 34). Money as a common good should be under the total control of the state (Degens 2013, p. 33). This reformation would lead a power shift in the financial world. Not only that money creation is in the hands of a public institution, but also because commercial banks do not have an advantage toward regular market participants anymore. Regular companies have to finance their own to 100 percent, but the banks only "fractional" with the legal minimum reserve. In a system of sovereign money this advantage does not exist (Mayer 2017).

In the European Union the European Central Bank is responsible for the control and guarantee of the money supply. It is the highest money and currency administration (Venhoff and Gräber-Seissinger 2004, p. 430). In consequence of the private bank money system and the accompanying tailspin over the money supply, the European Central Bank is constrained in its constitutional task (Felber 2014, p. 46). In a sovereign money system the central bank would regain control over the money supply which is equal to a monopoly of money. Cashless checkbook money would be converted into Sovereign Money and would receive the status of a complete legal tender (Huber 2014, p. 103). The commercial banks lose their possibility to maintain money creation based on fractional reserve banking. As an "issuer of first instance" the central bank will rise up as the one and only source of money (Huber 2014, p. 103). This change of the system is associated 
with a power shift. It goes so far that proponents of Sovereign Money denominate the central bank as a monetative power. The central bank administers a monetary policy that serves the interest of the currency area. The central bank regulates the whole financial and monetary system and the European administration has to create a financial economy in which the central bank takes over the task of a money supplier in the sense of a public service whereby this can differ from economic freedom (Mastronardi and Cranach 2010, p. 74). The central bank is still bound to the public interest but to the principle of proportionality. The financial market will still work after the concept of market and liberty.

In a system of Sovereign Money the central bank has complete control over the money supply because it is not only creating 10 percent of the money supply, as in our current system but 100 percent. The central bank decides directly and independently how much money circulates and is therefore independent from commercial banks in its control decisions. The indirect control of the money supply via interest rates becomes redundant and functions now as a framing and short term instrument of fine control (Huber 2014, p. 156). Based on this more effective and direct control over the quantity of money, it is possible to establish a monetary policy that is tailored to the cyclical development of the economy. The decisions over the quantity of money are made discretely and independently from the directives of politicians or other economic institutions (Felber 2014, p. 84).

Just as counterfeiting is illegal in our current system, the creation of private bank money or an equivalent substitute will be considered as fraud. This ensures that commercial banks will not seek possibilities to circumvent constraints toward money creation. From a historical point of view, positive money can be seen as the next evolutional step of money. It is based on the nationalization of banknotes in the 19th century (Huber 2014, p. 105).

So the step to a Sovereign Money system can be compared with the step to the nationalization of banknotes. It is just one step further, due to the fact that the non-cash private bank money gets declared as lawful money (Mastronardi and Cranach 2010, p. 125). From the view of Sovereign Money proponents, this is not a radical reformation of the currency system, but the refund of those rights to the central bank that have been taken with the invention of fractional reserve banking.

Another important question in connection with Sovereign Money that has to be answered is how this money is pictured in bank transfers. The answer is astonishingly simple. It has to be booked like cash. This means that the account "liabilities to customers" is not used anymore. The "money accounts of the customers" will be managed outside the balance sheet, similar to custody accounts.

The following five standard procedures of a bank can illustrate how it works.

Firstly, we take the example of a commercial bank granting a loan. In this example the commercial bank transfers the money from its own account to the account of the customer. Simultaneously a receivable emerges to the client (Mayer 2016). 
A transfer from one customer of the bank to another customer of the bank does not affect the balance sheet. It is transferred directly from customer account to the other customer account (Mayer 2016).

If money is transferred to a bank account that is managed by a different bank a kind of "postman" is necessary. In the case of a transfer of securities this is done by a clearing house (Mayer 2016).

The fourth example is a customer who wants to invest money in a savings account. In this case the customer transfers money from his account to the account of the bank. In return the customer receives a credit note. The bank can now use this money for lending (Mayer 2016).

In the last example the customer pays cash into the bank. The bank accepts this from the customer and swaps it against book money. The bank transfers money from its own account to the account of the customer. If the customer withdraws money from his account the same happens just in reverse (Mayer 2016).

\section{$100 \%$ Money}

The concept of Sovereign Money is not an entirely revolutionary approach. There are several concepts that can be seen as a precursor. One of the most famous is the so-called "100\% Money" by Irving Fisher (Dietl 2014). This concept was developed after the Great Depression in 1933. During the Great Depression the amount of money decreased by about 29 percent. This means that nearly one third of every dollar circulating before, disappeared during the crisis (Huber 2014). Although the idea of a $100 \%$ reserve had already come up during the 1930 's, it never existed in reality (Machaj 2017, p. 127).

According to Fisher commercial banks are supposed to hold permanently 100 percent cash reserves for the sight deposits of their customers. This is the reason why this concept is also called full reserve banking. The core of this concept is the abolishment of a fractional reserve banking system and includes separation of monetary and credit policy. Money creation is independent from the lending process.

The starting point of this concept is the fact that cashless payment transactions are predominating and exceeding cash transactions clearly. The state has no influence on the creation of private bank money.

The already-mentioned breakdown of the money supply is, according to the proponents of full reserve banking, one of the main reasons for the crisis from 1929 to 1933. Proponents argue that with full reserve banking strong increases and breakdowns in the money supply are reduced. This decreases the threat of inflation or deflation and stabilizes the system as a whole. The second advantage is the prevention of bank runs and the reduction of bank failures. All in all, it leads to a slowdown of booms and depressions and to stronger dependence on the real economy. The third advantage is the extraordinary reduction of debts due to the 
fact that money does not have to be created by public borrowing. The state can issue it directly (Degen 2013, p. 32).

If we compare these two reforming plans we can find commonalities but also fundamental differences. Both approaches share in that they identified a problem in the current private bank money system and regard this as one of the reasons for financial crisis (Huber 2014). We can also consider both approaches as a currency theory because both imply that the functions of money creation and financial intermediation are separable (Goodhart \& Jensen 2015, p. 1). Another important commonality is that the money supply is de facto created exogenously because all creation of money has to be covered by a 100\% reserve (Degens 2013, p. 31).

Furthermore, both approaches share that they analyze and criticize the fractional reserve system and the financing of public debt via credit. Additionally both approaches share the aim to end a possible bloat of the money supply by the private sector (Huber 2014). Further, both approaches do not want to change the currency system into a system of commodity money, where the value of money comes from the material the money is made of. Both approaches try to remain in a system of a fiat currency where money has value because a government or a law decided to declare it as official currency (Benoit 2011).

The differences occur when we have a closer look at the technical details, especially the process of creating money, the methods of booking and accounting, the transactions and partially the institutional arrangements (Huber 2014).

\section{Fractional reserve}

In order to understand 100 percent banking, one needs to understand the way the fractional reserve works. Fractional reserve banking is the banking method that is used in our current system. In short, it means that commercial banks hold only a small percentage of the amount of claims toward them as reserves (Committee on Banking and Currency 1964). The fractional reserve is the most common system in the world nowadays (Machaj 2017, p. 128).

In general, we distinguish between three actors in our financial system: the central bank, the commercial banks, and the public. The task of the central bank is to maintain price stability. Therefore, it subjects a constitutional protected interest and is by oneself entitled to emit the legal payment. In contrast there are commercial banks which pursue commercial interests. They provide plenty of financial services like granting loans, executing payment transactions, or the storage of their customers' money. Ordinary people use mainly financial services, whereas only few nonbank institutions have contact with the central bank. The interplay of central banks, commercial banks, and the public determines the procedure of the fractional reserve system with multiple money creation. In such a reserve system banks only have to deposit a fraction of their customers' deposits at the central bank (Singh 2009, p. 9). 
The actual creation of money takes place in commercial banks, where sight deposits that are generated via grant lending are booked on the current accounts as means of payment (Mayer 2014, p. 49). It is a matter of an informal public-private partnership in which the commercial banks perform their role of mainly money creators and the central banks are obliged to control (Huber 2014, p. 172).

So how is private bank money exactly created? In general, commercial banks are lending money to customers and credit this money to the corresponding account. That is the reason why this procedure is also known as credit creation. In a broader sense, credit creation does not only include money lending to private persons and companies but with private bank money financed purchases of assets as well (McLeay et al. 2014, p. 17). If commercial banks expand the asset side through such businesses, the purchased real estates, government bonds, or other assets are bought with their own created money or rather a corresponding credit in the amount of the purchase price. These businesses fall under the category of interbank trades and cover all transactions of financial instruments that are made between two credit institutions. Since these kinds of business are not caused by an interaction with a customer but in their own name and own account, they are summed up in own account trading (Witt 2013, p. 10). The accounting procedures for lending scriptural credits and the purchase of assets are basically the same. In both cases it is bank or credit money.

Let us assume that a commercial bank grants a credit to a customer, for example a mortgage. In this case the appropriate amount is credited to the customer's account. In this example an amount of $100,000 €$ is created via accounting record. What is crucial, is that this amount is not taken from existing savings or other reserves, it is created out of nowhere and this results in an extension of the balance sheet. The creation of money happens through book entry and the entry of the credit does not require preceding financing via already existing deposits (Nell 2015, p. 179). The money that is transferred to the account of the customer does not exist before the commercial bank creates it ex nihilo (Latin for "out of air/ nothing"). It does not come to an exchange on the asset side. It is important to bear in mind that the emerging consumption of this created money is not supported by production (Shostak 2017).

The money circulation in our current system is divided. On the one hand, there are transfers between banks which use central bank reserves. On the other hand, there is public circulation (non-bank circulation) based on private bank money. The circulation of interbanking and non-banking transfers never mix. It is technically impossible. Credit institutions are the interface of these two circulations. The major part of money circulation consists of book money. It is circulating between banks, states, private persons, and companies (Huber 2014).

Cash is not constitutional anymore, it is just a leftover of old times. It is purchased after measuring the payment practices, by the commercial banks from the 
central bank. The public exchanges cash with private bank money and vice versa. The original solid of modern money is non cash.

The interbanking and public circulation are connected through clearing and settlement in payment transactions. Inflows and outflows of checking accounts are constantly mutually offset. The resulting balance of one bank to another, as a liability or asset, is usually only a small amount compared to total turnover, and has to be balanced with central bank money (excess reserves). This allows the banking industry to create private bank money amounts that are many times higher than the cash reserve basis (multiple private bank money creation).

The banks create money via credit to customers and also when they buy bonds and tangible assets as long as they can book it on the asset side.

If the balance sheets are expanded to an extent, that reserves are missing in sum, these can be taken from the central bank. The central bank assigns new reserves to a new interest rate (sometimes higher, sometimes lower) but the money demand of commercial banks is always fulfilled. The determining requirements for money creation are de facto set by the commercial banks. The central bank is only reacting by financing the remainder (Huber 2014). This means that the money supply in a currency area is directly dependent on demand for money. Commercial banks only create money because someone is willing to borrow money from the commercial bank (Shostak 2017).

The core principle of the $100 \%$ approaches is to increase the fractional reserve of $2.5 \%$ to a $100 \%$ reserve. Commercial banks are supposed to cover the customer deposits in their balances with 100\% central bank money (Huber 2014).

\section{Conclusion: Sovereign Money and the difference from a $100 \%$ Reserve}

The biggest difference between Sovereign Money and 100\% Money is the fact that $100 \%$ Money is still a reserve system. Sovereign Money would cancel the reserve system. In a Sovereign Money system a reserve in a classical sense does not exist. It is deleted, just like split money circulation, with reserves on the one hand and private bank money on the other. In such a system only one sort of money exists. It circulates steadily in the form of liquid assets regardless of the economic actor (Huber 2014).

Sovereign Money does not require a covering through other financial instruments. The banking and financial industry remain an essential part of the economy.

The current checking accounts are converted into money accounts. The money circulates in the same manner regardless of the economic actor. The non-cash funds are no longer deposits but unconstrained property of the account holder. The commercial banks manage the accounts on behalf of their clients. 
In a system of $100 \%$ reserve, it is still necessary to offset the banking liabilities. In a Sovereign Money system this does not apply. In a Sovereign Money system money only gets transferred as a liquid asset. The money accounts of the customers are not part of the balance sheets of the bank. Money does not exist in any balance sheet as a liability. With $100 \%$ banking it still would. Money creation and lending are two separate procedures. The task of the central bank is money creation and control of the money supply. The lending and financing of other economic activities are tasks and business of commercial banks (Mayer 2017).

Commercial banks in a Sovereign Money system are money brokers or investors, but they cannot create money on their own anymore, which is the basis of their business right now (Mayer 2017).

Another difference is that in the Sovereign Money system the banks do not have automatically higher financing costs (Huber 2014). Especially in a time of zero interest rate policy does Sovereign Money not affect commercial banks financially. If a commercial bank creates money for free or is lending money at zero percent interest, it does not matter for commercial banks (Mayer 2017). With a top up of the fractional reserve to $100 \%$ the interest seignorage of the central bank increases tremendously. The interest margin of the commercial banks on the other hand nosedives, or the increased interest burden is passed on to the customers. The general interest level increases noticeably because the cost for holding a 100 percent reserve are additional costs that the economic actors have to pay.

The differences are also obvious when we look at safety precautions. In the fractional reserve system private bank money is always secured by mechanisms of a deposit guarantee by the state. This is still the case with 100 percent money. This 100 percent money is still money from commercial banks (Huber 2014).

Additionally, Sovereign Money is also supposed to finance a larger part of the national budget. A switch to a system of Sovereign Money offers the possibility to reduce the amount of public debt by one half or more, depending on the level of debt of the state. The reason is that the whole inventory of private bank money is sorted out and substituted with Sovereign Money. This substitution enables the central bank, or rather public funds, a transition seignorage amounting to the current private bank money stocks. Reducing public debt with this mechanism is only possible once during this transition, but still an interesting point that has to be taken into account (Degens 2013, p. 33).

\section{References}

Felber C. (2014), Geld — die neuen Spielregel, Vienna.

Machaj M. (2017), Money, Interest and the Structure of Production, London.

Mastronardi P., \& Cranach M. von (2010), Lernen aus der Krise: auf dem Weg zu einer Verfassung des Kapitalismus - ein Dossier von Kontrapunkt, Bern.

Mayer T. (2014), Die neue Ordnung des Geldes - warum wir eine Geldreform brauchen, Munich. 
Nell E.J. (2015), The Encyclopedia of Central Banking, Cheltenham.

Singh S.K. (2009), Banking Regulations, New Delhi.

Venhoff M., \& Gräber-Seissinger U. (2004), Der Brockhaus-Wirtschaft, Mannheim.

Witt M. (2013), Der Eigenhandel von Universalbanken - Aufbauorganisation, Erfolgsausweis und Möglichkeiten der Steuerung, Wiesbaden.

\section{Internet sources}

Benoit C., "Commodity money vs Fiat money", http://www.evancarmichael.com/library/christopherbenoit/Fiat-Money-vs-Commodity-Money.html (access: 3.03.2018).

Brächer M., "Warum sich Schweizer über Geldschöpfung aufregen", http://www.handelsblatt.com/my/ finanzen/geldpolitik/vollgeld-initiative-warum-sich-die-schweizer-ueber-geldschoepfung-aufregen/20956658.html?ticket=ST-364899-edZk6uSUn7pS3gr7zjpP-ap2 (access: 15.02.2018).

Committee and Banking and Currency (1964), Money Facts: 169 Questions and Answers on Money, http://www.baldwinlivingtrust.com/pdfs/AllAboutMoney.pdf (access: 18.01.2018).

Degens P. (2013), “Alternative Geldkonzepte”, http://monneta.org/wp-content/uploads/2015/10/Degens2012-Alternative-Geldkonzepte- $\%$ E2\%80\%93-ein-Literaturbericht.pdf(access: 2.01 .2018 ).

Dietl H. (2014), "Die Vorteile des Vollgeldes", https:/www.cash.ch/kolumne/die-vorteile-des-vollgeldes-183528 (access: 13.01.2018).

Goodhart C., \& Jensen M. (2015), "Currency school vs. banking school: An ongoing confrontation”, http://eprints.lse.ac.uk/64068/1/Currency\%20School\%20versus\%20Banking\%20School.pdf (access: 11.12.2017).

Huber J. (2014), "Vollgeld und 100\% Reserve", https:/www.dropbox.com/s/ury9ofcdl0vdymm/Vollgeld\%20und\%20100Prozent\%20Reserve.Chicago\%20Plan.pdf?dl=0 (access: 20.12.2017).

Kumhof M., \& Benes J. (2012), “The Chicago plan revisited”, http://www.imf.org/external/pubs/ft/ wp/2012/wp12202.pdf (access: 17.07.2018).

Mayer T. (2016), "Bilanzierung von Bankengeld und Vollgeld", http://www.initiative-monnaie-pleine. $\mathrm{ch} / \mathrm{fa} / \mathrm{img} /$ Vertiefung_deutsch/2016_10_01_Bilanzierung_von_Vollgeld.pdf(access: 13.01.2018).

Mayer T. (2017), "Fragen und Antworten zur Vollgeld-Initiative", https://www.vollgeld-initiative.ch/ fa/img/Texte_Dokumente_deutsch/2017_01_Vollgeld_Fragen_web.pdf (access: 14.04.2018).

McLeay M., Radia A., \& Thomas R. (2014), "Money creation in the modern economy", https:// www.monetary.org/wp-content/uploads/2016/03/money-creation-in-the-modern-economy.pdf (access: 3.01.2018).

Schöchli H. (2017), "Der Nationalrat lehnt die Vollgeld-Initiative klar ab", https://www.nzz.ch/ schweiz/der-nationalrat-lehnt-die-vollgeld-initiative-klar-ab-ld.1339304 (access: 14.12.2017).

Shostak F. (2017), Fractional reserve banking and money creation, https://mises.org/blog/fractional-reserve-banking-and-money-creation (access: 20.01.2018). 